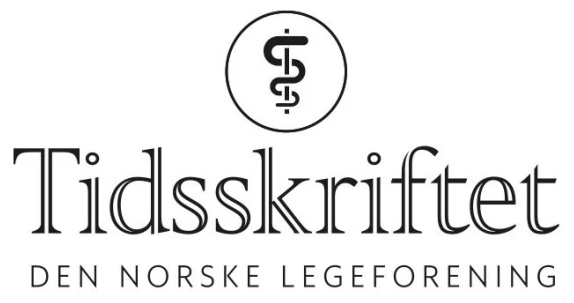

\title{
Trangt om saligheten
}

TIDLIGERE I TIDSSKRIFTET

ÅSLAUG FLO

Email: aaslaug.flo@legeforeningen.no

Tidsskriftet

Det er ikke bare i dag det kan være vanskelig å skaffe seg tak over hodet. I «de harde trettiåra» var bolignøden stor, og mange måtte ta til takke med krypinn «som på grunn av elde, mangelfullt vedlikehold, soppangrep m. m. er uskikket til å huse mennesker. Det er boliger som er fuktige, mørke, trekkfulle, vanskelig å gjøre rene, uten vann og kloakk o. s. v.». I Tidsskriftet nr. 20/1936 drøfter Axel Strøm helserådets adgang til å «forby («kondemnere») boliger som det finner mislige...», selv om han modererer seg ved å hevde: «Det er neppe tvil om at boligenes innflydelse på helsen har vært adskillig overdrevet så vel av publikum som læger. Eller, for å si det mere forsiktig, vår viden på dette område er ennu så mangelfull, at man bør være meget varsom med å uttale sig om boligforholdenes innvirkning på sundheten. De senere års erfaringer synes å tyde på at sammenlignet med andre hygieniske faktorer som $\mathrm{f}$. eks. ernæringen spiller boligforholdene en mindre rolle.» Ut fra avsnittet under å dømme kan det i hvert fall ikke være tvil om at folk hadde liten plass (Tidsskr Nor Lægeforen 1936; 56:1125-37).

Fra Oslo helseråds avdeling for bolighygiene. Om «kondemnerte» boliger.

Av Axel Strøm, Oslo. 


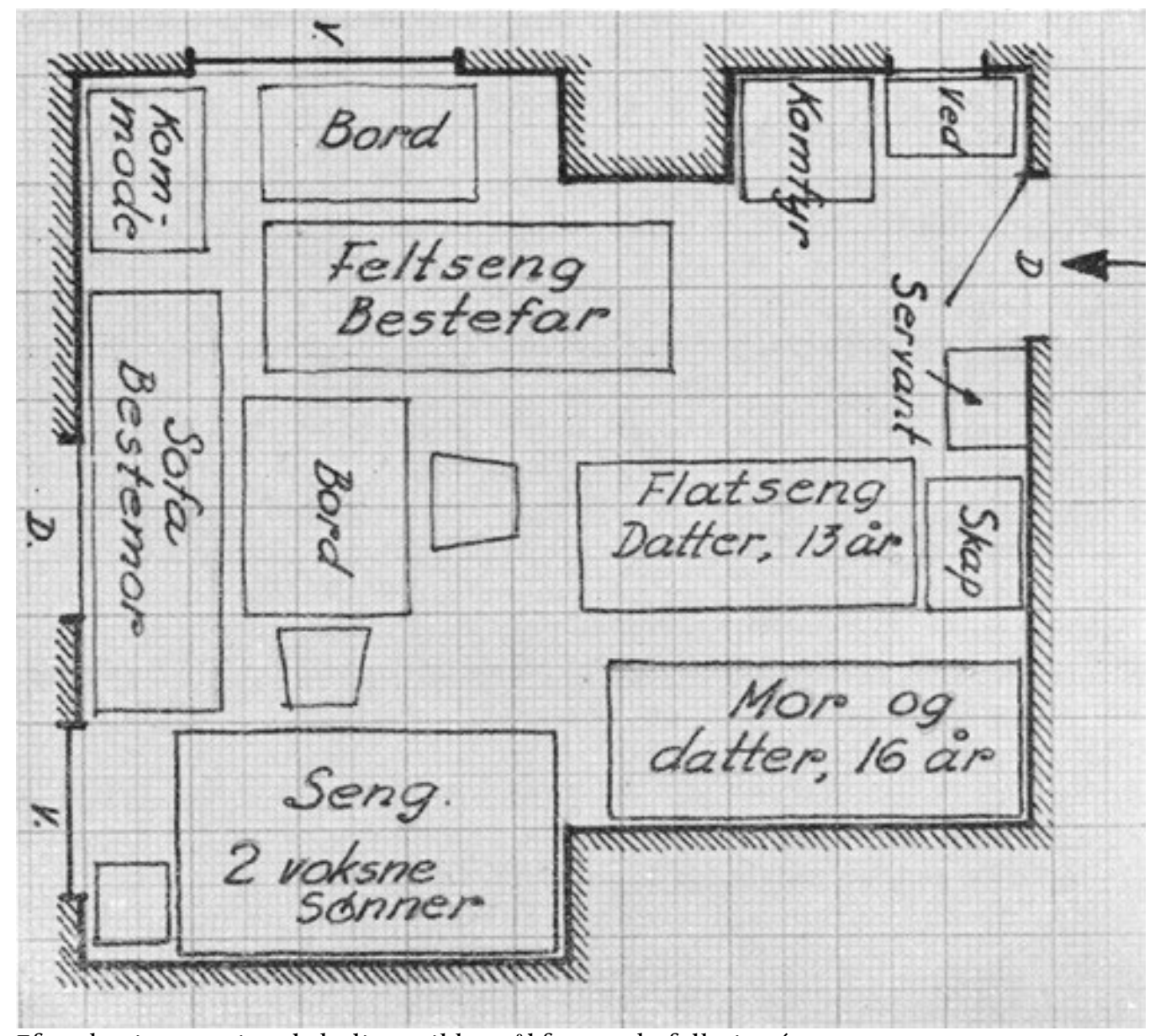

Efter den internasjonale boligstatikks mål for overbefolkning (mere enn 2 personer pr. rum, kjøkken iberegnet) var 17 leiligheter $=11$ pct. overbefolket. Efter Oslo sundhetsvedtekters mål (minst $10 \mathrm{~m} .{ }^{3}$ pr. individ over 10 år og minst $5 \mathrm{~m} .{ }^{3}$ pr. individ under 10 år i leilighetens våningsrum) var 32 av leilighetene $=21$ pct. overbefolket i utilladelig grad. Den verste overbefolkning fantes i en rønne i Lakkegaten hvor der i et elendig rum på $15 \mathrm{~m}^{2}{ }^{2}\left(33 \mathrm{~m}^{3}{ }^{3}\right.$ ) bodde 7 voksne personer av begge kjønn. Fig. 3 viser et riss av rummet med soveplassene inntegnet.

Publisert: 6. mars 2012. Tidsskr Nor Legeforen. DOI: 10.4045/tidsskr.12.0189

(C) Tidsskrift for Den norske legeforening 2023. Lastet ned fra tidsskriftet.no 26. april 2023. 